\title{
INFLUENCE AND CONTRIBUTION OF CHINA IN SOUTH ASIA
}

Sahibzada Muhammad Usman*

\section{Abstract}

This paper mainly examines the influence and contribution of China in South Asia. After the declaration of the 'Belt Road Initiative' (BRI), China has driven the strong advancement of infrastructure programmes in the countries of South Asia. Despite China have made a successful condition all through the Indian Ocean Region, pragmatist researchers contend that Beijing's goals are to use this infrastructure to make abroad bases; compromise the influence of India, and expand Chinese influence by challenging the order of the region. At the point when seen in a moderate way, the activity makes open doors for infrastructure advancements, supports multilateral development, and address the disappointment that current worldwide and local organizations might not be able to survive. By choosing perspective to see China's aims, the influences in South Asia can evaluate how to tackle these projects and either support or challenge China.

Keywords: South Asia, China, BRI, Investment, Influence

\section{INTRODUCTION}

The Chinese government presented BRI activity. The activity expands China's financial links in South Asia by consolidating infrastructure ventures (Xinhuanet, 2015). Because of the projects, China hopes to grow closer associations with the nations of South Asia to reach a successful condition by infrastructure development and more frequent trade cooperation (Yun, 2015). Belt and Road proceed with an inheritance of over ten years of Chinese-drove ventures all through South Asia and is formed another concentration and upgraded interest in the region. As China keeps on developing this economic

"Ph.D. Scholar, Department of Political Science, University of Pisa, Italy. Email: usman@studenti.unipi.it (Corresponding author) 
connection behind the BRI activity, liberal scholars contend that China is looking to make a positive environment in which China and South Asian countries stay in mutual advantage through expanded trade capacities, more grounded financial cooperation, and multilateral economy. Considering all the situations, pragmatists contend that China is using this project to create territorial strength, challenge the existing region order, and make open doors abroad basing all through the Indian Ocean basin. This paper emphasises what China's commitments in South Asia are? For this, the paper has used a typical structure that evaluated BRI through various apparent influences on South Asia. The various viewpoints were sought to analyse from security, economic, and political perspectives.

The information from Chinese authorities and news sources contain the focal point of the project released by the authority of China and is the BRI policy paper. The document forms the infrastructure and standards of BRI by showing China's goals for the project.

\section{RESEARCH METHOD}

This research is based on secondary data and qualitative interpretive approach is used to critically analyse data. Simultaneously, various infrastructure ventures and economic connections among China and South Asian counties: Bangladesh, Pakistan, India, Myanmar, and Sri Lanka were analysed. These countries were chosen because of their importance in the region. The existence of China drove infrastructure tasks in their borders; as well as the financial relations between China and them.

\section{DISCUSSION AND ANALYSIS}

During an official visit to Pakistan (2015), President Xi Jinping ventured almost 46.5 billion US dollars on the geostrategic criticalness of Pakistan (Rida, 2018). Accepting the sub-mainland as the point of convergence of Beijing's currently declared the BRI activity, Xi stated that South Asia is the place where the oceanic and land roads meet. 
The BRI is becoming the overwhelming focus in the Chinese diplomatic policy for the improvement of Asian economies. President Xi Jinping declared in the Pakistani Parliament that China had driven a critical move to open in the new conditions completely. This project additionally shows China's duty of sharing improvement chances and results with more nations.

However, there is a long way to link China with South Asia through a broad arrangement of transportation infrastructure. China has looked to advance railways, ports and roads to coordinate within the region. It is perceived that start of the Karakoram Highway gives a way to link China both politically and economically with its neighbour nations. Currently, the BRI is a new proof of an increased interest of Chinese-drove projects all through South Asia. China has been setting the territorial infrastructure programme that focused on linking China to South Asia by means of Chinese-created transportation infrastructure. With China using the nations of South Asia as a center point of the economy to the global market, the ongoing infrastructure activities are open doors for China to advance financial course through business and the development of assets. Accordingly, China is introducing the new stage in the economic opening of China and arranging all previous infrastructure plans in South Asia.

\section{Opportunities for China}

China's first endeavour to soften the feelings of fear of its Asian nations at the Bandung Conference, China has constantly kept up a calm condition to aid the improvement of the worldwide network. Added to the Five Values of Peaceful Existence, there are advanced messages of equivalent development, respect for freedom, and winwin collaboration, which found in the start section of the BRI. This paper links the activity to the soul of the BRI 'participation and peace, inclusiveness and openness, shared advantage and shared learning'. As China is changing to a developed state or service-based market, 
the project displays a requirement for China to explore externally. Where before, the Chinese GDP has been tied down by the nation's exports, Chinese President Xi Jinping's statement demonstrates a craving to develop a GDP upheld by local consumption (Greg, 2015). To consider this move, which will bring about more demand for outside products and natural assets, China is looking for chances to open an extra door to get these merchandise and assets.

Likewise, the proposed infrastructure gives advantages to customarily poor zones all through China. With huge numbers of the planned BRI projects associating poor western areas of China to both the eastern coast and neighbouring nations, the economic inflow toward the western territories will lighten the monetary tumble off (Scott \& David, 2015). Accordingly, the connection between China's east and west can give economic equalization through the programme's capacity to all the more likely circulate the colossal industrial ability of China to its western regions. Additionally, the development of ports near the Indian Ocean and interfacing transport passageways over the border of China give new paths to proceed with political links and business cooperation with the nations of Middle East and the Gulf (Muhammad, 2015). However, the investigation has discovered that sea business through Malacca to eastern Chinese seaboard is unquestionably more productive and financially efficient than overland transport through the range of mountain. The advantage comes in the port abilities accessible to Chinese traders and Navy Army that have started wandering further from China's coasts (Gabe \& Andrew, 2010).

\section{South Asian railways and roads}

The Karakoram Highway was intended to be the focal point of China Pakistan Economic Corridor (CPEC) linking western China via Pakistan to the Indian Ocean and with extra plans declared to remerge and broaden the roads. The CPEC links the Gwadar port of Pakistan to Xinjiang area of China. Xi's ongoing help of the development shows Beijing's wish to carry the vision to realization. 
Moreover, Chinese development projects in Nepal, Tibet, Myanmar, and Bangladesh with more than 145 roads linking China to neighbouring Asian nations. With funding apportioned in 2011 for another railway between Kyaukpyu and Kunming, the task settled in 2014 because of public resistance on asset mining by China that was considered to misuse the authority of Myanmar (Jacob, 2014). Moving to Tibet Independent Area, there are cases of railways and roads connecting neighbouring nations to underdeveloped western regions of China.

At the start of 2006, the railroad made the probability for upcoming ventures in geographically challenging segments of Bhutan, Nepal, and north-eastern India. Reported in 2008, China expressed intentions to stretch out the Lhasa railroad to the Nepal borders. After a year, the local administration of Tibet extended the effectively adjoining roads at the expense of almost 100 million US dollars with expectations to develop a second road to Nepal. Furthermore, if that was insufficient to exhibit the Beijing's expectations, current reports from the media of China guarantee that China is building a tunnel to link Kathmandu with the rail by 2020 .

\section{New access to the world}

China gives chances of economic growth all through its western areas. The port areas are doorways to Europe, Africa, and the Middle East by giving oceanic transportation that connects back to the mainland of China. Therefore, China keeps on funding transportation infrastructure projects in Bangladesh, Sri Lanka, Myanmar, and Pakistan. The Gwadar port of Pakistan links toward the KKH's connecting roadway infrastructure and gives China a favourable position because of its vicinity to the Strait of Hormuz (Rorry, 2013, p. 95). Primarily, it is decreasing the high traffic in the Karachi port, the Chinese looked into the project in 2001 in the wake of promising to subsidize 198 million US dollars of the development expenses by the China Harbour Corporation that managed development. The port 
formally began in the mid-2007 under the activity of the Singapore Port Expert. At the start of 2008, the port second period of development slow over the legitimate conflict between the PSA and the Pakistani government. At last, the Singaporeans quit the agreement, and port tasks accepted by the China Overseas Port Holdings Company (2013). As Chinese regulator of the port, its US $\$ 46$ billion investment in pipelines, highways, and railways that show, 'China plans to change into a free commerce zone follow Hong Kong or a Singapore' (Jack, 2015).

Perceiving the opportunities to approach the Indian Ocean, China has funded more tasks in different nations such as Sri Lanka, Bangladesh, and Myanmar. For instance, by funding of US \$361 million in the first stage and US $\$ 808$ million in the second stage, that banks of China covered a segment of the expense to finish the port in Sri Lanka, and accordingly, increased functioning to four berths (Namini, 2014). A similar event reported that China consented to finance the $\$ 9$ billion of the evaluated expense to manufacture the port of Chittagong (Mukul, 2010). Combined with the railways and road infrastructures that associate a large number of ports connect different nations with China, these tasks broaden the economic courses into the nation by joining extra shipping paths that keep away from critical bottlenecks, for example, exceptionally trafficked worldwide shipping path via the Strait of Malacca.

\section{Multiple projects merge}

The official presentation of BRI (2015) endeavours to bringing together the past and future projects under a solo strategy. The projects join two past activities, which are the Silk Road Economic Belt and the $21^{\text {st }}$ Century Maritime Silk Road. While discussing at Nazarbayev University, $\mathrm{X}$ i Jinping explained the significance of financial ties among Central Asian nations and China and the support trade activities through the improvement of transport networks in the region. During the official visit of Xi Jinping to Indonesia, the second part of the BRI revealed. Talking before the Indonesian Parliament on 
the significance of keeping up a solid connection among China and the ASEAN nations, $\mathrm{Xi}$ vowed to fortify oceanic connections to Southeast Asian neighbours by the advancement of the BRI. Planned as to extend practical participation with ASEAN nations, $\mathrm{Xi}$ announced that the programme prevails by helping one another, so as together taking advantage of lucky breaks and meeting difficulties for the benefit of mutual improvement and flourishing (ASEAN, 2013).

Moreover, to plans for political solidarity and infrastructure advancement, the two new economic infrastructures, the Silk Road Fund and the Asian Infrastructure Investment Bank, were signed. Started in 2014 and at first sponsored by 21 nations, the AIIB enrolment has been increased to 57 nations and is endeavouring to support the around 760 million US dollars yearly infrastructure space (Don \& Ong, 2014). With China's access to the financial infrastructure in the Asian market; some contend that organizations, for example, the World Bank and the IMF must retool their positions to consider expanded Chinese impact. In any case, with the adjustments in these infrastructures delayed happen, the ascent of the AIIB exhibits a conceivable solution for the comparable absence of governance matters that burden other developing nations. In 2014, the SRF intended to use local and global wealth to fund BRI tasks and search out investment openings during the advancement of the BRI. In the Economic Cooperation Summit in 2014, Xi Jinping guaranteed US \$40 billion as the opening investment (Paul \& Ben, 2014). Combined with the AIIB, the backing of these infrastructures exhibits eagerness by the universal network to support China's arrangement for financial integration and to solve an unsatisfactory infrastructure in the imperative economic area of the world.

The Ministry of Commerce, the National Development Commission, and Foreign Affairs of China released a combined paper in 2015, which officially laying out the standards of the BRI. The paper starts by talking about the infrastructure, standards, and structure of the 
Initiative before enumerating the needs, tools, and regional interest. Depending vigorously on the past foreign strategy of China concerning shared advantages and common respect, the Initiative tries to form 'another Eurasian Land-Bridge' that uses industrial estates in joining nations as collaboration stages.

The paper also clarifies the achievement of this Initiative will be estimated on the capacity to make the infrastructure important for the free-move of technology and trade, the essential idea is the advancement of basic improvement, financial combination, and maintaining China's five standards of peaceful existence (Kennedy, Scott \& David, 2015). Both local and international strategy view on this activity is a solid step advancement for Beijing. Locally, China looks to use BRI to advance economic development all through its western territories. As Chinese President planned in regards to the development of these areas. Globally, the Initiative is an open door for China to bear extra duties as a rising worldwide authority and enhance its picture according to South Asia and other forces: China focused on bearing more duties and commitments in its capacities and making more important commitments to the advancement and peace of humankind (Derek, 2020).

\section{The infrastructure helps to develop the interests of China}

The BRI is making a win condition and giving financial chances to those nations that band together with China. Because of the guarantees of 'regular improvement' and 'win-win collaboration' that China acted as the focal point of the BRI. The liberal contention worries about the concern of confirmation to show proof of financial progression in joining nations. It underpins the thought which thing useful for China is useful for the nations of South Asia, with clear proof demonstrating that a huge increase in two-sided investment and trade in the previous decade. However, as nations like Sri Lanka keep on falling more into debt with Chinese banks, as of now almost 8 billion US dollars, there is aim to contend against mutual development (Nilanthi, 2019). Besides, realists point to the absence of 
development at the domestic stage as a symbol that the activity is not moving the nations of South Asia from high position to low position (Sanjeev, 2019). Rather, they push the story that BRI is essentially to furnish China with roads to make up for its 'Malacca Dilemma'.

The proof demonstrated these infrastructure tasks are in truth, making investment and trade chances all through South Asia. By Beijing following up on a need to ship more prominent amounts of assets all through the region, China is making market open doors for those eager to be partners with Chinese organizations. The realist contention misses the mark that Beijing is capable if these nations neglect to deal with their loan-level or appropriately disseminate profits down to the domestic level.

\section{BRI impact in the neighbour nations}

Through the improvement of the infrastructure of China, it is obvious to the two sides that Beijing will have a more noteworthy impact on South Asian issues. The liberal point of view that the infrastructure has made economic passages, which are slanting toward more noteworthy inclusion by China in settled multilateral organizations. Taking note of China, who moves from viewer position to active member position in South Asian Association for Regional Cooperation (SAARC), the liberals also contend that this shows eagerness with respect to China to grip multilateral organizations and tie itself with decisions worried about the region's more noteworthy things (Hempson \& Justin, 2005). Realist researchers do not agree with this idea of the tied power of local organizations and economic passages by contending that BRI supports just those nations that keep up prevalent help for China. It suggests that nations associated with Belt and Road will stay faithful to China, and China can utilize these connections to facilitate its very own motivation, which will infringe on India's power. One example is China's ongoing cooperation with Pakistan. By demonstrating such outward help, as a $\$ 46$ billion infrastructure bundle, China is proving to be India's most noteworthy 
opponent (Raghavan, 2013).

No solid proof that could associate with the development of a foundation with desires by China for paybacks from the host nation. While it may be guileless to imagine that there would be obvious proof of such an association, any sign of China rising such doubts during its determination procedure is dismissed by the way that Beijing has held a solid comprehensive nature about its projects. It has kept up an open approach to acknowledge all nations into BRI and its multilateral organizations to incorporate India. For sure, an unmistakably economic challenge between both adversaries yet does not compare to China endeavouring to engage nations that contradict India. Thus, there is more proof to help the possibility that Beijing's expanded connection in local politics demonstrates a common worry for the course of the region, due to some degree to its monetary needs. Also, less proof demonstrating China wants to infringe on India's power.

\section{Reason for the seaports}

The focal point of the discussion over China's inspirations stays in the 'string of pearls'. This suggests that China is financing ports strategically near the Indian Ocean to circle India, overwhelm the Indian Ocean Region, and extend Beijing's range of prominence (Kostecka, 2011). Accepting that there is a strategy to the franticness, Indian researchers claim that China's activities intended for the sole motivation behind counterbalancing India (Bajaj, 2010). Aggressive realists are of the view that Beijing's activities are predictable with stage zero tasks intended to make choices to move troops and assets for future military activity. Generally speaking, this hypothesis has more evidence to support their claim. Thus, liberal researchers give a more grounded contention by introducing proof that straightforwardly repudiates realist theories. In discrediting this hypothesis, there are two explicit bits of proof that best express the liberal case. Firstly, string of pearls was unequipped for supporting significant battle activities. Secondly, there is a minimal strategic 
preferred position for Beijing to draw militaries from its built-up seaside defences to guard the India Ocean Region. Subsequently, most liberals concur that "China's pearls" give off an impression of being what China means they are: customary shipping services intended to associate China's western regions to sea business courses.

\section{The challenge for economic stability}

China challenges western administration by decreasing USA partly in South Asian matters (Yale \& William, 2015). By working outside the American veto, China equipped for pushing a planned encounter to Washington's objectives (Smith, 2015). The White House expresses that America has retained its help of the organization over an absence of transparency. Liberals stand this fear by contending that Beijing's activities are because of needs that the past organizations are not able to tackle. China is trying to address the elective share difference and finance around 760 million US dollars yearly infrastructure gap across Asia through the AIIB.

What's more, liberals' argument with the impacts of such organizations as proof that Beijing is connecting itself with other nations. By making an infrastructure in which Beijing compelled to vote that comprises all nations of South Asia, except Bhutan and Afghanistan, there are clear wilful limits to China's capacities in the infrastructure (Junio \& Don, 2014). While it appears to be valid that Beijing is endeavouring to improve an infrastructure that it is less attached to American view, and little proof to demonstrate that it expects to make an infrastructure wherein China itself swaps America to controlling vote-particularly since decided not to look for veto control in the AIIB (Alain, 2015). With America and Japan have critical hold outs, the permission of India and local players bring up issues to the apparent apprehensions that these nations may have of China utilizing these organizations to propel a China-driven motivation. Mutual infrastructures are broad connections established in participation and mutual development. It is hard to envision a 
situation in which China can control a multilateral advancement bank to push a plan that solely advantages China.

\section{CONCLUSION}

China started investing in the nations of South Asia infrastructure since clear economic benefits by both the host country and China. With business expanding by 45 billion US dollars, there is motivation to accept that an expansion in the infrastructure will keep on making extra advantages. Likewise, if China keeps on free-ride to small nations by bank moving huge costs, as observed in Bangladesh and Sri Lanka, then Belt and Road will meet its main goal of a more prominent network and a success win condition. China has to ship more prominent amounts of assets in the growing market opportunities all through the area and making real benefits for South Asian nations.

The comprehensive nature of projects like AIIB and BCIM, combined with the willingness with respect to China to join previous associations like SAARC, shows an effective decision by China to put resources into nearby multilateral organizations and tie itself to choices worried about the region's more noteworthy trade. Regardless of fears that these activities may be China's endeavour to collect enough help to start managing directions and terms, to this point, China has not shown such aims. Rather, China's expanded interest is the consequence of its economic requirements, which demonstrated to give advantages to the region as well.

While realists contend that new financial organizations of China challenge current worldwide and local infrastructures by decreasing U.S.'s part in the nations of South Asia, and the structure and comprehensive nature of these projects are the pointers that BRI is progressively steady with a liberal focal point. As the AIIB in a customary shape, it shows that Beijing acknowledges the advantages of the present order and just tries to adjust it instead of changing it. Furthermore, the comprehensive idea of these infrastructures is not 
just deliberately restricting China's very own capacity in local matters. Yet, additionally, it is expanding the intensity of local contenders, for example, India. Through these new comprehensive organizations and all the conditions kept into consideration.

Finally, there is no proof that China is misusing the oceanic infrastructure to grow abroad bases. China must stand with its public position that they would not make any broad military or naval centres, and it must keep up a military procedure that does not look for authority or military extension. Any sign of a military extension will promptly discredit China's argument and uncertain good links between China and India.

\section{REFERENCES}

Alain, G. (2015). Confront or accommodate? The Maritime Silk Road will test U.S.-China rivalries. Retrieved from https://www.globalasia.org/article/confront-oraccommodate-the-maritime-silk-road-will-test-us-chinarivalries/

ASEAN. (2013). Speech by Chinese President Xi Jinping to Indonesian Parliament. Retrieved from http://www.asean-chinacenter.org/english/2013-10/03/c_133062675.htm

Bajaj, V. (2010). India worries as China builds ports in South Asia. New York Times. Retrieved from https://www.nytimes.com /2010/02/16/business/global/16port.html

Derek, G. (2020). What China wants in South Asia? Retrieved from https://www.orfonline.org/research/what-china-wants-insouth-asia-67665/

Don, R., \& Ong, J. (2014). Asian infrastructure investment Bank: An idea whose time has come? The Diplomat. Retrieved from http://thediplomat.com/2014/12/asian-infrastructureinvestment-bank-an- idea-whose-time-has-come/ 
Gabe, C., \& Andrew, E. (2010). Still a pipedream: A Pakistan-to-China rail corridor is not a substitute for maritime transport. China Signpost. Retrieved from http://www.chinasignpost.com /2010/12/22/still-a-pipedream-a-pakistan-to-china-railcorridor-is-not-a-substitute-for-maritime-transport/.

Greg, K. (2015). So what is China's 'One Belt One Road' Thing, Anyway? Retrieved from http://www.joc.com/internationaltrade-news/so-what-china's-'one-belt-one-road'-thinganyway_20150407.html.

Hempson, J., \& Justin, S. (2005). The evolution of China's engagement with international governmental organizations. Asian Survey, 45(5), 702-721.

Jack, D. (2015). China's grand plan for Pakistan's infrastructure, The Diplomat. Retrieved from http://thediplomat.com/2015/04/ chinas-grand-plan-for-pakistans-infrastructure/.

Jacob, G. (2014). Myanmar's great power balancing act. The Diplomat. Retrieved from http://thediplomat.com/2014/08/myanmarsgreat-power-balancing-act/.

Kennedy, S., \& Parker, D. A. (2015). Building China's 'One Belt, One Road. Retrieved from http://csis.org/publication/buildingchinas-one-belt-one-road.

Kostecka, D. J. (2011). Places and bases: The Chinese Navy's Emerging Support Network in the Indian Ocean. Naval War College Review, 64(1), 59-78.

Muhammad, D. F. (2015). The China-Pakistan Economic Corridor: Potential and vulnerabilities. The Diplomat. Retrieved from http://thediplomat.com/2015/05/the-china-pakistaneconomic-corridor-potential- and-vulnerabilities/.

Mukul, D. (2010). Is Chittagong one of China's 'String of Pearls? Retrieved from http://news.bbc.co.uk/2/hi/business /8687917.stm. 
Namini, W. (2014). China gets controlling stake at Hambantota Port. Sunday Times. Retrieved from http://www.sundaytimes.lk /141019/news/china-gets-controlling-stake-at-hambantotaport- 123262.html

Nilanthi, S. (2019). China's engagement with smaller South Asian countries. United States Institute of Peace. Retrieved from https:/www.usip.org/publications/2019/04/chinasengagement-smaller-south-asian-countries

Paul, C., \& Ben, B. (2014). China to establish $\$ 40$ billion Silk Road infrastructure fund. The Reuters. Retrieved from http://uk.reuters.com/article/uk-china-diplomacyidUKKBNOIS0BU20141108

Raghavan, S. (2013). Stability in Southern Asia: India's perspective. In A.J. Tellis \& S. Mirski, (Eds.). Crux of Asia: China, India, and the emerging global order, (pp.135-144). Washington, DC: Carnegie Endowment for International Peace.

Rida, K. (2018). China's growing influence in South Asia. The Nation. Retrieved from https://nation.com.pk/05-Aug-2018/china-sgrowing-influence-in-south-asia

Rorry, D. (2013). Strategic Competition in South Asia: Gwadar, Chabahar, and the Risks of Infrastructure Development, American Foreign Policy Interests, 35(2):93-100.

Sanjeev, K. (2019). China's South Asia policy in the new era. A journal of International Affairs. Retrieved from https://journals.sagepub.com/doi/full/10.1177/ 0974928419841769

Smith, J. M. (2015). Beware China's grand strategy: How Obama can set the right red lines. Foreign Affairs. Retrieved from https://www.foreignaffairs.com/articles/china/2015-0520/beware-chinas-grand- strategy 
Xinhuanet. (2015). Chronology of China's 'Belt and Road initiatives'. Retrieved from http://news.xinhuanet.com/english/china /2015-02/05/c_133972101.htm.

Yun, S. (2015). Inserting Africa into China's One Belt, One Road Strategy: A new opportunity for jobs and infrastructure? Brookings Institute. Retrieved from http://www.brookings.edu/blogs/africa-in-focus/posts/ 2015/03/02-africa-china-jobs-infrastructure-sun 